\title{
PADDY HUSK ASH AS A SOURCE OF POTASSIUM FOR GROWTH AND YIELD OF COWPEA (Vigna unguiculata L.)
}

\author{
$\mathrm{J}$ Priyadharshini ${ }^{1}$ and $\mathrm{T} H$ Seran $^{1}$
}

\begin{abstract}
An experiment was conducted to study the effect of paddy husk ash as a source of potassium on growth and yield of cowpea (Vigna unguiculata L.). The treatments included recommended rate $\left(0.075\right.$ ton/ha) of muriate of potash as a control $\left(T_{1}\right)$ and application of paddy husk ash at the rate of $1.5\left(T_{2}\right), 2.5\left(T_{3}\right), 3.5\left(T_{4}\right)$ and $4.5\left(T_{5}\right)$ tons/ha. This experiment was laid out in a Randomized Complete Block Design with four replications in sandy regosol. The agronomic parameters were recorded at regular intervals. Result revealed that there were no significant differences among treatments especially for number of seeds and dry weights of leaves, stem and root. However, number of nodules, number of pods, dry weight of pod and 100 seed weight were significantly varied among treatments. It was further noted that application of paddy husk ash at the rate of 4.5 tons/ha gave high yield (1.44 tons/ha) followed by $T_{1}\left(1.42\right.$ tons/ha) and $T_{4}(1.35$ tons/ha). The application of paddy husk ash at the rate of 4.5 tons/ha is suitable for obtaining high yield of cowpea in sandy regosol. Hence paddy husk ash could be used as a source of potassium in cowpea cultivation due to the potential constraint of chemical fertilizer and the benefits of organic farming in Sri Lanka.
\end{abstract}

Keywords: Cowpea, paddy husk ash, potassium, yield, fertilizer

\section{INTRODUCTION}

Land use is optimized through technologies and management practices. The current practice in agriculture is basically chemical based farming that makes considerable degradation of natural resources, particularly soils. Therefore, various approaches have been tried out on the use of available and renewable resources of plant nutrients for complementing and supplementing the commercial fertilizers. As a result, efforts were made to systematically evaluate the feasibility and efficacy of organic residues, not only refurbishing soil productivity but also in promoting the efficiency of chemical fertilizers (Bhardwaj, 1995; Terazawa, 1999; Ariyaratne, 2000).

The combined use of organic and inorganic fertilizers in crop production has been widely recognized as a way of increasing yield and improving productivity of the soil (Mamaril et al.,
1999). Agricultural activities produce billions of tons of other materials long regarded as waste. The main types of agricultural wastes are crop residues and farm animal wastes (Bruttini, 1923). Meaningful contributions to soil nutrient dynamic pool and beneficial effects on subsequent crops have been reported when crop residues were returned to land and especially if the residues are of immediate utilizable form (Shanmugam et al., 1996). With appropriate techniques, agricultural wastes can be recycled to produce an important source of energy and natural fertilizer for crops. Recycling agricultural wastes can help a developing country to reduce its dependence on foreign energy supplies and raise the standard of living in its rural areas (Pequegnat, 1975).

In Sri Lanka, paddy husk is highly available amendment in large quantities It has reasonable quantities of cations $\mathrm{Ca}$, $\mathrm{Mg}, \mathrm{K}, \mathrm{Na}$, and other essential elements 
including $\mathrm{P}$ and very little $\mathrm{N}$. Paddy husk ash from various locations contains $0.72-$ $3.84 \% \quad \mathrm{~K}_{2} \mathrm{O}$ and $0.23-1.59 \quad \mathrm{MgO}$ (Muthadhi et al., 2007). Bronzeoak Ltd (2003) reported that potassium and phosphorous contents of paddy husk ash were $0.01-2.69 \% \quad \mathrm{P}_{2} \mathrm{O}_{5}$ and $0.1-2.54 \% \mathrm{~K}_{2} \mathrm{O}$ respectively and the $\mathrm{pH}$ was 08.1-11.0. The ash increases the soil $\mathrm{pH}$, thereby increasing available phosphorous, it improves the aeration in the crop root zone and also increases the water holding capacity and level of exchangeable potassium and magnesium (AICOAF, 2001).

Amount of potassium vary with the temperature and time which the husk burnt, therefore it can be used as potassium source for crop production. Potassium is one of sixteen essential nutrients required for plant growth and reproduction and it is classified as a macronutrient, as are nitrogen and phosphorus (Marschner, 1995). Potassium is supplied by inorganic fertilizers such as muriate of potash or sulphate of potash or complex fertilizers, or by some organic sources.

Cowpea is a grain legume that is widely cultivated and consumed throughout the world. It is popular for its high grain protein content (14\% to $33 \%)$. These are the main source of dietary protein for the people, especially for the large vegetarian population. The protein in cowpea seed is rich in amino acids, lysine and tryptophan. These crops are generally included in crop rotation to help maintaining soil fertility and productivity. Being nitrogen fixing crops, their value as green manure has long been recognized. Grain legumes can be fitted into diverse cropping systems and thrive under a range of agro climatic condition. Cowpea is cultivated throughout the year in all agro-ecological regions and the paddy husk ash is highly available amendment in large quantities in Sri Lanka. Recycling of crop residues is an integral part of integrated plant nutrition which is now being increasingly recognized as the strategy for sustaining high crop yield level with minimal depletion of soil fertility or fall in its other quality aspects (Bhardwaj, 1995). Therefore, an attempt was made to study the effect of paddy husk ash as a source of potassium on growth and yield of cowpea in sandy regosol.

\section{MATERIALS AND METHODS}

An experiment was conducted during Maha season 2008/2009 at the Agronomy farm, Eastern University, Sri Lanka. This experiment was laid out in a Randomized Complete Block Design with five treatments and four replicates. Plot size was $2 \mathrm{~m} \times 2 \mathrm{~m}$. Paddy husk ash as a source of potassium was applied to soil at different levels as basal application of fertilizer. Treatments in this experiment are given in Table 1 and recommended dose of muriate of potash was used as a control. Before being carried out the research work, phosphorous and potassium contents of paddy husk ash used in this experiment were analysed. It showed that $1.31 \% \mathrm{~K}_{2} \mathrm{O}$ and $0.66 \% \mathrm{P}_{2} \mathrm{O}_{5}$ contained in paddy husk ash.

In this experiment, seeds of cowpea variety, Dhawala were used. Seeds were sown at the rate of 0.035 ton/ha and at the spacing of $45 \mathrm{~cm}$ between rows and $15 \mathrm{~cm}$ between plants. Basal application of fertilizers was done two days before planting. Urea at the rate of 0.035 ton/ha, Triple Super Phosphate at the rate of 0.1 ton/ha were applied to all plots. Sources of potassium applied were given in Table 1 . Top dressing was done at the rate of 0.03 ton/ha of urea at the onset of flowering to all the treatments. Other cultural practices were followed as recommended by Department of Agriculture, Sri Lanka. 
Twelve plants were randomly selected from each treatment to measure the agronomic parameters. All data collected for experimental purposes were statistically analyzed by analysis of variance (ANOVA) and the mean separation were done using Duncan's Multiple Range Test at 5\% level.

Table 01: Source of paddy husk ash and rate of application to soil.

\begin{tabular}{clc}
\hline Treatments & Source of potassium & Application rate (tons/ha) \\
\hline $\mathrm{T}_{1}$ & Muriate of potash & 0.075 \\
$\mathrm{~T}_{2}$ & Paddy husk ash & 1.5 \\
$\mathrm{~T}_{3}$ & Paddy husk ash & 2.5 \\
$\mathrm{~T}_{4}$ & Paddy husk ash & 3.5 \\
$\mathrm{~T}_{5}$ & Paddy husk ash & 4.5 \\
\hline
\end{tabular}

Note: Muriate of Potash contains $60 \% \mathrm{~K}_{2} \mathrm{O}$ (Ariyaratne, 2000). Potassium content of paddy husk ash used in this experiment was analyzed. It had $1.31 \% \mathrm{~K}_{2} \mathrm{O}$.

\section{RESULTS AND DISCUSSION}

\section{Number of flowers}

Table 2 shows the number of flowers formed at $5^{\text {th }}$ and $6^{\text {th }}$ weeks after planting. There was no significant difference $(\mathrm{P}>0.05)$ in mean number of flowers at $5^{\text {th }}$ week among treatments. Even though there was no significant difference, the number of flowers appeared to be high (5.25) in the treatment with paddy husk ash at the rate of 4.5 tons/ha $\left(\mathrm{T}_{5}\right)$ and the lowest (4.08) was in $\mathrm{T}_{2}$ (1.5 tons/ha paddy husk ash). It was also noted that there was an apparent increase in number of flowers from $T_{2}$ to $T_{5}$. At the $6^{\text {th }}$ week after planting, the mean number of flowers ranged from 3.58 (in $\mathrm{T}_{2}$ and $\mathrm{T}_{3}$ ) to 3.83 (in $\mathrm{T}_{5}$ ). It recorded as 3.75 in $\mathrm{T}_{1}$. Mean number of flowers increased with an increase of application rate of paddy husk ash in this experiment. The quantity of $\mathrm{K}^{+}$ releasing to the nutrient dynamic pool is the dominant factor on growth of Cowpea.

\section{Number of pods}

Table 3 indicates that the number of pods per plant was significantly different $(\mathrm{P}<0.05)$ among treatments, but there was no significant difference between the treatment with application of muriate of potash (0.075 ton/ha) $\left(\mathrm{T}_{1}\right)$ and the treatment with paddy husk ash 4.5 tons/ha $\left(T_{5}\right) . T_{1}$ showed slightly higher number of pods than $T_{5}$, this may be due to the slow release of potassium from paddy husk ash compared to the muriate of potash. Among treatments, $T_{2}$ (7.87) significantly recorded low number of pods per plant. This might be application of low level of potassium supplemented by ash. Potassium is essential for photosynthesis and pod development in groundnut (Burkhart and Collins, 1941). Yakardi et al (1992) reported positive response for number of pods per plant and 100 kernel weight by application of potassium. 


\section{Number of seeds per pod}

The mean number of seeds per pod ranged from 7.25 (in $\mathrm{T}_{2}$ ) to 8.67 (in $\mathrm{T}_{5}$ ) and there was no significant variation in number of seeds among treatments. However, $\mathrm{T}_{2}$ appeared to be having slightly low mean number of seeds per pod. Hence, comments of Reddy (1988) on reducing seed number in response to low level of potassium fertilizer in peanut cultivation was not clearly found in this experiment.

Table 02: Effect of paddy husk ash on number of flowers

\begin{tabular}{ccc}
\hline & \multicolumn{2}{c}{ Number of flowers } \\
Treatments & At $5^{\text {th }}$ week & At $6^{\text {th }}$ week \\
\hline $\mathrm{T}_{1}$ & $5.25 \pm 0.95$ & $3.75 \pm 0.95$ \\
$\mathrm{~T}_{2}$ & $4.08 \pm 0.56$ & $3.58 \pm 0.31$ \\
$\mathrm{~T}_{3}$ & $4.53 \pm 0.41$ & $3.58 \pm 0.56$ \\
$\mathrm{~T}_{4}$ & $5.16 \pm 0.31$ & $3.66 \pm 0.49$ \\
$\mathrm{~T}_{5}$ & $5.91 \pm 0.40$ & $3.83 \pm 0.49$ \\
F test & $\mathrm{ns}$ & $\mathrm{ns}$ \\
\hline
\end{tabular}

Table 03: Effect of paddy husk ash on number of pods per plant

\begin{tabular}{cc}
\hline Treatments & Number of pods \\
\hline $\mathrm{T}_{1}$ & $10.25 \pm 0.94^{\mathrm{a}}$ \\
$\mathrm{T}_{2}$ & $07.87 \pm 0.12^{\mathrm{c}}$ \\
$\mathrm{T}_{3}$ & $08.00 \pm 0.54^{\mathrm{bc}}$ \\
$\mathrm{T}_{4}$ & $09.87 \pm 0.42^{\mathrm{bc}}$ \\
$\mathrm{T}_{5}$ & $10.00 \pm 0.84^{\mathrm{a}}$ \\
F test & $*$
\end{tabular}

Value represents mean \pm standard error of four replicates.

F test:*: $\mathrm{P}<0.05$

Means followed by the same letter are not significantly different according to Duncan's Multiple Range Test at 5\% level 


\section{Fresh weight of plant}

The fresh weight of stem showed significant variation $(\mathrm{P}<0.05)$ among treatments (Table 4) but there was no difference between treatment with 3.5 tons/ha paddy husk ash $\left(\mathrm{T}_{4}\right)$ and treatment with 4.5 tons/ha paddy husk ash $\left(\mathrm{T}_{5}\right)$. This was similar to the finding of Fawzy et al. (2005) who showed that potassium fertilizer had a significant effect on the fresh weights of leaves and stems, early and total yield of sweet pepper plants. Fresh weight of leaves showed significant difference among treatments. $\mathrm{T}_{5}$ had high mean fresh weight of leaves (14.78) and significantly differed from other treatments except $T_{4}$. This result is supported by Chen et al. (1996) on eggplant and Al-Karaki (2000) and Gupta and Sengar (2000) on tomato plant who mentioned that increasing vegetative growth is due to increasing potassium fertilizer levels.

Fresh weight of roots exhibited no significant difference ( $\mathrm{P}>0.05)$ among treatments, but the highest root weight was recorded in treatment with 4.5 tons/ha paddy husk ash $\left(\mathrm{T}_{5}\right)$, and the lowest was in the treatment with 1.5 tons/ha $\left(\mathrm{T}_{2}\right)$. The weight of pods was significantly varied $(\mathrm{P}<0.05)$ among the treatments as shown in Table 4. The result revealed that the weight of pods was high in $\mathrm{T}_{5}$ and low in $\mathrm{T}_{2}$, this decline is supported by Cheng et al. (1999) who found that potassium uptake of plants and thus plant growth declines rapidly with decreasing potassium release.

Table 04: Effect of paddy husk ash on fresh weight of plant after harvesting.

\begin{tabular}{lcccc}
\hline & \multicolumn{4}{c}{ Fresh weight of plant $(\mathrm{g})$} \\
Treatment & Leaves & Stem & Root & Pod \\
\hline $\mathrm{T}_{1}$ & $04.78 \pm 1.79^{\mathrm{bc}}$ & $47.40 \pm 1.97^{\mathrm{b}}$ & $3.08 \pm 0.31$ & $26.33 \pm 1.44^{\mathrm{ab}}$ \\
$\mathrm{T}_{2}$ & $03.48 \pm 1.92^{\mathrm{c}}$ & $36.59 \pm 1.95^{\mathrm{b}}$ & $2.62 \pm 0.20$ & $19.44 \pm 1.59^{\mathrm{b}}$ \\
$\mathrm{T}_{3}$ & $06.59 \pm 2.84^{\mathrm{abc}}$ & $40.12 \pm 1.26^{\mathrm{b}}$ & $3.30 \pm 0.29$ & $22.70 \pm 1.84^{\mathrm{ab}}$ \\
$\mathrm{T}_{4}$ & $12.76 \pm 4.36^{\mathrm{ab}}$ & $47.43 \pm 3.03^{\mathrm{a}}$ & $3.39 \pm 0.72$ & $26.85 \pm 1.54^{\mathrm{a}}$ \\
$\mathrm{T}_{5}$ & $14.78 \pm 2.68^{\mathrm{a}}$ & $48.04 \pm 1.95^{\mathrm{a}}$ & $3.47 \pm 0.19$ & $26.64 \pm 3.83^{\mathrm{a}}$ \\
& $*$ & $*$ & $n$ & $*$ \\
\hline
\end{tabular}

Value represents mean \pm standard error of four replicates.

F test:*: $\mathrm{P}<0.05$; ns: not significant

Means followed by the same letter in each column are not significantly different according to Duncan's Multiple Range Test at 5\% level

\section{Dry weight of plant}

The summary of result pertaining to biomass production as recorded in terms of mean dry weight at harvest is presented in Table 5. There were no significant treatment differences $(\mathrm{P}>0.05)$ in the mean dry weights of stem, leaves and roots. This result is in agreement with Melton and
Dufault (1991) who reported that potassium did not significantly influence any of the growth parameters of tomato plants such as shoot and root dry weights. Significant difference $(\mathrm{P}<0.05)$ was found in the mean dry weight of pods. The mean dry weight of the pods ranged from 10.41 (in $\mathrm{T}_{2}$ ) to 17.93 (in $\mathrm{T}_{5}$ ). $\mathrm{T}_{5}$ showed a significant difference from $\mathrm{T}_{2}$. This 
simulative effect may be due to the role of potassium on production of enzyme activity and enhanced translocation of assimilative and photosynthesis (El-Desuki et al., 2006).

Table 05: Effect of paddy husk ash on dry weight of cowpea

\begin{tabular}{ccccl}
\hline & \multicolumn{4}{l}{ Dry weight of plant $(\mathrm{g})$} \\
Treatments & Leaves & Stem & Root & Pod \\
\hline $\mathrm{T}_{1}$ & $1.38 \pm 0.77$ & $38.89 \pm 4.10$ & $1.56 \pm 0.16$ & $15.54 \pm 3.37^{\mathrm{ab}}$ \\
$\mathrm{T}_{2}$ & $1.72 \pm 0.54$ & $34.24 \pm 3.06$ & $1.13 \pm 0.18$ & $10.41 \pm 1.23^{\mathrm{b}}$ \\
$\mathrm{T}_{3}$ & $2.49 \pm 1.17$ & $37.89 \pm 2.46$ & $1.60 \pm 0.29$ & $13.58 \pm 2.70^{\mathrm{ab}}$ \\
$\mathrm{T}_{4}$ & $4.01 \pm 0.98$ & $41.17 \pm 1.21$ & $1.65 \pm 0.43$ & $16.61 \pm 2.12^{\mathrm{ab}}$ \\
$\mathrm{T}_{5}$ & $4.25 \pm 0.95$ & $44.04 \pm 4.50$ & $1.70 \pm 0.14$ & $17.93 \pm 1.09^{\mathrm{a}}$ \\
$\mathrm{F}$ test & $\mathrm{ns}$ & $\mathrm{ns}$ & $\mathrm{ns}$ & $*$ \\
\hline
\end{tabular}

Value represents mean \pm standard error of four replicates.

F test:*: $\mathrm{P}<0.05$; ns: not significant

Means followed by the same letter in each column are not significantly different according to Duncan's Multiple Range Test at 5\% level

\section{Nodule formation}

The number of nodules was significantly varied $(p<0.05)$ among the treatments. The high number of nodules was recorded in the application of 4.5 tons/ha paddy husk ash $\left(\mathrm{T}_{5}\right)$ followed by $\mathrm{T}_{4}$ (Table 6). There was no significant variation between $T_{1}$ and $T_{5}, T_{2}$ had the lowest number of nodules. The result obtained is similar to Collins and Duke (1981) who revealed that in legumes, potassium deficit may cause inadequate supply of sugars to root nodules, which greatly reduces rates of $\mathrm{N}_{2}$ fixation and export of bound nitrogen. Further, Seripong (1988) who concluded that phosphorous and rice husk ash improved nodulation in Thailand soils, and Perkins (1924) indicated increase in soyabean nodulation with potassium fertilizer and liming. This is also confirmed by Poschenrieder and Lesch (1943) who reported that potassium enhances the nodulation of soyabean. Fresh and dry weights of nodules were varied significantly $(p<0.05)$ among the treatments, $T_{5}$ showed significantly high fresh and dry weights. This was confirmed by the study of Jones et al. (1977) who stated that the number and weight of soyabean nodules increased as $\mathrm{K}$ nutrition improves. 

Table 06: Effect of paddy husk ash in nodule formation of cowpea

\begin{tabular}{cccc}
\hline Treatments & Number of nodules & Fresh weight $(\mathrm{g})$ & Dry weight $(\mathrm{g})$ \\
\hline $\mathrm{T}_{1}$ & $5.00 \pm 1.22^{\mathrm{ab}}$ & $0.20 \pm 0.03^{\mathrm{c}}$ & $0.09 \pm 0.21^{\mathrm{c}}$ \\
$\mathrm{T}_{2}$ & $3.25 \pm 1.16^{\mathrm{b}}$ & $0.15 \pm 0.01^{\mathrm{c}}$ & $0.06 \pm 0.01^{\mathrm{c}}$ \\
$\mathrm{T}_{3}$ & $4.00 \pm 0.54^{\mathrm{b}}$ & $0.17 \pm 0.01^{\mathrm{c}}$ & $0.07 \pm 0.00^{\mathrm{c}}$ \\
$\mathrm{T}_{4}$ & $6.25 \pm 1.56^{\mathrm{ab}}$ & $0.74 \pm 0.02^{\mathrm{b}}$ & $0.33 \pm 0.01^{\mathrm{b}}$ \\
$\mathrm{T}_{5}$ & $7.87 \pm 0.62^{\mathrm{a}}$ & $1.02 \pm 0.11^{\mathrm{a}}$ & $0.45 \pm 0.03^{\mathrm{a}}$ \\
$\mathrm{F}$ test & $*$ & $*$ & $*$ \\
\hline
\end{tabular}

Value represents mean \pm standard error of four replicates.

F test:*: $\mathrm{P}<0.05$

Means followed by the same letter in each column are not significantly different according to Duncan's Multiple Range Test at 5\% level

\section{0 seed weight}

Seed weight is a major determinant of the yield of cowpea. The effect of treatments on 100 seed weight is given in Table 7. The result revealed that there was significant difference $(\mathrm{P}<0.05)$ among the treatments. Treatment with application of muriatic of potash (0.075 tons/ha) $\left(\mathrm{T}_{1}\right)$ showed slightly high seed weight and followed by the treatment with paddy husk ash 4.5 tons/ha $\left(\mathrm{T}_{5}\right)$. Significantly lower mean seed weight was found in $\mathrm{T}_{2}$, may be due to lower supplement of potassium. The total seed yield was also found to be increased with increasing level of ash. This is in conformity of reports by Touchton (1982) who showed that corn yield and seed weight increased as potassium nutrition improves. Sale and Campbell (1986) reported that potassium deficient soils are likely to produce crops with low yields and low seed oil levels in soyabean.

\section{Yield}

The result on yield showed a significant variation $(p<0.05)$ among treatments. The highest yield (1.44 tons/ha) was obtained in the application of paddy husk ash at the rate of 4.5 tons/ha $\left(\mathrm{T}_{5}\right)$ while the lowest yield (0.79 ton/ha) was obtained in $\mathrm{T}_{2}$
(Table 7).This result is supported by Marschner (1995) who reported that potassium deficiency in plants, export of photosynthate from source leaves (e.g., young, photosynthetically active leaves) to other organs decline due to a decrease in osmotic potential in the sieve tubes. Also Grimme (1974) showed as the contribution from non-exchangeable $\mathrm{K}$ increases, the yield declines. However, there was no significant yield deviation among the application of Muriate of potash and the addition of ash except $T_{2}$. These results are in agreement with the finding of Seripong (1988) who concluded that phosphorous and paddy husk ash improved nodulation, yield and some soil properties of Thailand soil. Okon et al. (2005) stated that the optimum level of rice husk ash plus 0.05 ton urea per ha can sustain rapid growth and better yield of okra even faster than NPK, because rice husk ash contains almost all other essential plant nutrients and the presence of nitrogen will boost their uptake. The yield increase was supported by numerous authors who reported that the total yield, marketable yield and total average yield per plant were increased by increasing application rates of potassium as reported by Singh and Verma (1991), Gupta and Sengar (2000), HarneetKaur et al. (2003) and Kotepong et al. (2003) on tomato plants. 

Table 07: Effect of paddy husk ash on 100 seed weight and yield of cowpea

\begin{tabular}{ccc}
\hline Treatments & Seed weight $(\mathrm{g})$ & Yield (tons/ ha) \\
\hline $\mathrm{T}_{1}$ & $19.18 \pm 1.02^{\mathrm{a}}$ & $1.42^{\mathrm{a}}$ \\
$\mathrm{T}_{2}$ & $16.37 \pm 0.90^{\mathrm{b}}$ & $0.79^{\mathrm{d}}$ \\
$\mathrm{T}_{3}$ & $17.15 \pm 0.77^{\mathrm{ab}}$ & $1.01^{\mathrm{c}}$ \\
$\mathrm{T}_{4}$ & $18.89 \pm 0.98^{\mathrm{ab}}$ & $1.35^{\mathrm{b}}$ \\
$\mathrm{T}_{5}$ & $19.02 \pm 0.74^{\mathrm{a}}$ & $1.44^{\mathrm{a}}$ \\
& $*$ & $*$ \\
\hline
\end{tabular}

Value represents mean \pm standard error of four replicates.

F test:*: $\mathrm{P}<0.05$

Means followed by the same letter in each column are not significantly different according to Duncan's Multiple Range Test at 5\% level.

\section{CONCLUSIONS}

There were significant treatment differences in dry weight of pods. In this experiment, the 100 seed weight was high in $T_{1}$ (19.18), but this does not significantly differ from $\mathrm{T}_{5}$ (19.02). Application of ash had significant effect in number and weight of nodules among the treatments. Application rate of 4.5 tons/ha resulted the high number of nodules and nodule weight. Significant differences of yield could be found among treatments. Application of paddy husk ash at the rate of 4.5 tons/ha gave high yield (1.44 tons/ha) followed by $\mathrm{T}_{1}$ (1.42 tons/ha) and $\mathrm{T}_{4}$ (1.35 tons/ha). Therefore, it would be concluded that application of paddy husk ash as a source of potassium at a rate of 4.5 tons/ha is favorable for yield advancements in cowpea. In Sri Lanka, paddy husk ash is a highly available and cheap amendment in large quantities. Hence, application of paddy husk ash is best suited to small scale farming in sandy soil.

\section{References}

AICOAF, (2001). Application of rice husk charcoal. Food and Fertilizer Technology Center for the Asian and Pacific region leaflet for Agriculture: Practical Technologies 4. Association for international Cooperation in Agriculture and Forestry (AICOAF), Japan.

Al-Karaki, G. N. (2000). Growth, sodium, and potassium uptake and translocation in salt stressed tomato. Journal of Plant Nutrition, 23(3), pp: 369-379.

Ariyaratne, R. M. (2000). Integrated Plant Nutrition Systems (IPNS) training manual (Sri Lanka). The Fertilizer Advisory, Development information network for Asia and the Pacific (FADINAP). Bangkok, Thailand, pp: 140.

Bhardwaj, K. K. R. (1995) Recycling of crop residues, oil cakes and other plant production in agriculture. In: Recycling of crop, animal, human and industrial wastes in agriculture (Ed. H.L.S Tandon). Pub Fertilizer Development \& consultation organization, New Delhi, pp: 9-27.

Bronzeoak Ltd (2003). Report of the rice husk ash market study, Bronzeoak Ltd, UK, pp: 62. 
Bruttini, A. (1923). Use of Waste Materials. P. S. King and Son Ltd, Westminster, England, pp: 367.

Burkhart L. and E. R. Collins (1941). Mineral nutrient in peanut plant growth. Proceedings of Soil Science Society of America, 6, pp: 272-280.

Chen Zhen De, Huang Jun Jie and Cai Kui (1996). Studies on fertilizer application levels of seedling stage of eggplant raised with mixed media. China Vegetables, 4, pp16-18.

Cheng Mingfang, Jin Jiyun and Huang Shaowen (1999). Release of native and nonexchangeable soil potassium and adsorption in selected soils of North China. Better Crops International, 13 (2), pp: 3-5.

Collins, M. and S. H. Duke (1981). Influence of potassium-fertilization rate and form on photosynthesis and $\mathrm{N}_{2}$ fixation of alfalfa. Crop Science, 21, pp: 481-485.

EL-Desuki M, M. M. Abdel-Mouty and A. H. Ali (2006). Response of Onion Plants to Aditional Dose of Potassium Application. Journal of Applied Science Research, 2(9), pp: 592-597.

Fawzy, Z. F., A. G. Behairy and S. A. Shehata (2005). Effect of potassium fertilizer on growth and yield of sweet pepper plants (Capsicum annuum, L.) Egypt Journal of Agriculture Research, 2(2), pp: 599-610.

Grimme, H (1974). Potassium release in relation to crop production. In: Proceedings of. $10^{\text {th }}$ Congress Intern. Potash Institute, Budapest, Hungary, pp: 131-136.

Gupta, C. R. and S. S. Sengar (2000). Response of tomato (Lycopersicon esculentum Mill.) to nitrogen and potassium fertilization in acidic soil of Bastar. Vegetable Science, 27(1), pp: 94-95.

Harneet-Kaur, Thakur, J. C. and Neena-Chawla (2003). Effect of nitrogen and potassium on growth, yield and quality of tomato (Lycopersicon esculentum Mill.) cv. Punjab Upma. Haryana Journal of Horticultural Sciences, 32(3/4), pp: 286-288.

Jones, G. D., J. A. Lutz, Jr., and J. Smith (1977). Effects of phosphorous and potassium on soybean nodules and seed yield. Agronomy Journal, 69, pp: 1003-1006.

Kotepong, P., Thongket, T., Kamlung, A. and J. Verasan (2003). Effect of nitrogen and potassium on growth and yield of cherry tomato cv. CH154 in hydroponics. Proceedings of $41^{\text {st }}$ Kasetart University Annual Conference on Plants and Agricultural Extension and Commnication, Thailand.

Mamaril, C., Gonzales, V., Olegario, A. and W. Obcemea (1999). Integrated Plant Nutrient management system in the Philippines: Review and Analysis. The Fertilizer Advisory, Development information network for Asia and the Pacific (FADINAP). Bangkok, Thailand, pp :117.

Marschner, H. (1995). Mineral nutrition of higher plants. Second Edition Academic press London. pp: 889.

Melton, R. R. and R. J. Dufault (1991). Nitrogen, phosphorus, and potassium fertility regimes affect tomato transplant growth. Horticultural Science, 26(2), pp :141-142.

Muthadhi, M., Anitha, R. and S. Kothandaraman (2007). Rice husk ash properties and its uses A Review. Journal of the Institution of Engineers (India) 88, pp: 50-55.

Okon Paul B., Ogeh Joseph S. and C. Amalu Uche (2005). Effect of Rice Husk Ash and Phosphorus on Some Properties of Acid Sands and Yield of Okra. Communications in Soil Science and Plant Analysis, 36(7), pp: 833-845.

Pequegnat, C. (1975). Waste Recycling and Canadian agriculture. In: Proceedings on Commercial Uses of Wastes and Animal Feed. Agricultural Economics Research Council, Canada, pp: 253.

Perkins A. T (1924). The effect of several mineral fertilizers upon nodulation of Virginia soybean. Soil Science, 17, pp: 439-447. 
Poschenrieder, H, and W. Lesch (1943), Untersuchungen u ber den Einfluzy langjarger Rin seitiger Düngungsbnahmen auf die: Ausbilding and Nährstoffaufnahme der Wurzel Knöllchen von sojabohnen. Bodenkd. Pflanzenernaehr, 32, pp :1-16.

Reddy P. S (1988). Groundnut. Indian Council of Agricultural Research, New Delhi, pp :101 $-333$.

Sale P. W. G. and L. C. Campbell (1986). Yield and composition of soyabean seed as a function of potassium supply. Plant and Soil, 96(3),pp: 317-325.

Seripong, S (1988). Responses of cowpea to applications of phosphorus and burned rice husk in an acid soil. Thai Journal of Agricultural Science, 21 (1), pp: 1-11.

Shanmugam, M., Rathnasamy, R., and N. Nadarajan (1996) Effect of amendments on soil properties and yield parameters under maize-black gram cropping sequence in soils with surface crusting. Madras Agricultural Journal, 83(1), pp: 24-36.

Singh, S. S. and S. K. Verma (1991). Influence of potassium, zinc and boron on growth and yield of tomato (Lycopersicon esculentum Mill.). Vegetable Science, 18(2), pp: 122129.

Terazawa, M. (1999). Biological clean up of biomass wastes using sawdust as an artificial soil matrix. In Proceeding of the International Symposium on Tropical peat lands, Hokkaido University and Indonesian Institute of Sciences, Bogor, Indonesia. pp: 101107.

Touchton, J. T (1982). Starter fertilizer for no tillage system. In: Research report of Potash and Phosphorous Institute, Atlanta, pp: 1-3.

Yakardi, M., Hussain, M.M and V. Satiyanarayana (1992). Response of rainfed groundnut (Arachis hypogaea L.) to potassium with varying levels of nitrogen and phosphorus. Indian Journal of Agronomy, 37(1), pp: 202-203. 